\title{
Türkiye Tarım Kredi Kooperatifleri İçin Kurumsal Risk Yönetimi ve İç Denetim Model Önerisi*
}

\author{
Enterprise Risk Management And Internal Audit Model Proposal for Turkish Agricultural Credit \\ Cooperatives
}

\author{
Maşuk Cahit UYSAL \\ Dr., Başmüfettiş (CICP, ISO/IEC 27001 BD), \\ Türkiye Tarım Kredi Kooperatifleri Merkez Birliği, \\ muysal@tarimkredi.org.tr \\ https://orcid.org/0000-0001-8196-0764
}

\author{
Durmuş ACAR \\ Prof. Dr., Burdur Mehmet Akif Ersoy Üniversitesi, \\ IIBF, Işsletme Bölümü, Muhasebe ve Finansman A.B.D., \\ dacar@mehmetakif.edu.tr \\ https://orcid.org/0000-0003-4701-6045
}

\begin{abstract}
ÖZET
Anahtar

Kelimeler:

İ̧ Denetim,

İç Kontrol,

Kurumsal

Yönetim,

Risk,

Teftis,

Örgütlerdeki önemi ve fonksiyonu bakımından denetim tartışılmaz bir faaliyettir. Denetimin rolünü gerçekleştirebilmesi için de yerinde yapılandırılmalıdır. Kamu İ̧̧ Kontrol Standartları doğrultusunda kamu kurumlarl, riskleri tanımlamak, değerlendirmek ile izlemeye yönelik sistem kurmaları gerekmektedir. Risk belirleme faaliyetleri, kamu kurum stratejilerinin kararlaştırıldı̆̆ planlama prosedürlerine entegre şekilde yürütülmelidir. Risk yönetimi örgüt hedeflerinin tutturulmasında ehemmiyet teşkil etmesi ile iç denetim birimlerinin de bu hususta danışmanlık hizmeti vermesi düşünülmektedir. Türkiye Tarım Kredi Kooperatiflerinde denetim faaliyetleri merkez birliğine bağll müfettişler ile bölge birliklerine bağll kontrolörler marifetiyle yürütülmektedir. Teftiş, inceleme ve soruşturma konularında bu birimler arasinda görev çakışması bulunmaktadır. Bu kapsamda çalışmanın amacı, Türkiye Tarım Kredi Kooperatiflerinde etkin iç kontrol ile iç denetim sisteminin nasıl uygulanabileceğini ortaya koymaktır. Çalışmada ilk olarak, Kurumsal Risk Yönetimi ile iç denetim kavramları açıklanmıştır. Uygulama kısmında ise, gerekli şartları sağlayan risk temelli bir iç denetim süreci için model önerisi sunulmuştur. Araştırma neticesinde Türkiye Tarım Kredi Kooperatiflerinde de Kurumsal Risk Yönetimi ve iç denetim konularında çalışmalar yapılması gerektiği tespit edilmiştir.
\end{abstract}

Keywords:

Enterprise

Management,

Internal Audit,

Internal Control,

Inspection,

Risk,

\section{ABSTRACT}

Audition is an indisputable activity in terms of its importance and function in organizations. Audit must be properly configured to perform its role. Public administrations must create a system to define, evaluate and monitor risks per Public Internal Control Standards. Risk defining activities need to be carried out integrated with the planning processes where public administration strategies are determined. The consensus of opinion is that risk management is critical for achieving institutional objectives, and that internal audit units should conduct consulting activities in this regard. Audit activities in Turkish Agricultural Credit Cooperatives is carried out through inspectors affiliated with the central union and controllers affiliated with the regional unions. There is a conflict of duty between these units in terms of inspection, investigation and investigation. In this context, the purpose of the study is to demonstrate how to implement an effective internal control and internal audit system for Turkish Agricultural Credit Cooperatives. In the study, firstly, Enterprise Risk Management and internal audit concepts are explained. In the implementation part, a model proposal for a risk based internal audit process that provides the necessary conditions is presented. It is determined necessary to carry out studies on Enterprise Risk Management and internal audit subjects in Turkish Agricultural Credit Cooperatives.

* Bu makale, 2017 yılında Süleyman Demirel Üniversitesi Sosyal Bilimler Enstitüsünde Prof. Dr. Durmuş ACAR danışmanlığında hazırlanan ve kabul edilen "Kamu Kurumlarında Kurumsal Risk Yönetimi ve Risk Odakl İ I̧ Denetim: Bir Model Önerisi”" adlı doktora tezinden üretilmiştir. 


\section{GIRISS}

Toplumların bilgi devrine geçmesiyle birlikte, kamu yönetimi de bu gelişmelerin etkisinde kalarak gelişmelere uyum sağlamıştır. Küreselleşme ve iletişim alanlarındaki hızlı gelişmeler, hem sektörler hem de ülkeler bazında üretim, ticaret ve yönetim alanlarında büyük değişimlere neden olmuştur. Kamu yönetim sistemi, bürokrasi, hantal yapısı ve yeni yönetim yaklaşımlarından bihaber insan kaynakları ile toplumun beklentileri karşısında yetersiz kalmış ve kendini değişimin içinde bulmuştur. Böylece kamu kesimi, verimlilik, etkinlik, etkililik ve hedef odaklı olma gibi özel sektörde var olan başarılı uygulamaları hayata geçirmeye başlamıştır. Bu durumda kamu yönetim sistemi, günümüz koşullarına uyum sağlayarak kamu hizmetlerinden faydalananların ihtiyaçlarını karşılama noktasında etkili bir araca dönüşmeyi amaçlamaktadır. Bir başka değişle, özel sektördeki iyi uygulamalardan hareketle kamu sektöründe benzer şekilde toplumu önemseyen, şeffaf, hesap veren yönetim sistem talepleri oluşmakta, bu talepler doğrultusunda da kamu yeni yönetim usullerini uygulamak durumunda kalmaktadır.

Ülkemizin Avrupa Birliği’ne üyelik görüşmeleri ve kamu yönetim yapısında topluluk standartlarına uyum çalışmaları da, kamu sektöründe yaşanan değişimde büyük rol oynamaktadır. Üyelik hedefi çerçevesinde kamu mali yönetimi konusunda $\mathrm{AB}$ ve uluslararası standartlar ile uyumu sağlayabilmek için "Mali Kontrol başlıklı 32. Fasıl"ın 26 Haziran 2006 tarihinde açılmasıyla birlikte bazı düzenlemeler yapılmıştır. Yapılan düzenlemelerin belki de en önemlisi, 1050 sayılı Muhasebe-i Umumiye Kanunu'nun yerine, 5018 sayılı Kamu Mali Yönetimi ve Kontrol Kanunu'nun yürürlüğe konulmasıdır. Kamu Mali Yönetimi ve Kontrol Kanunu ile birlikte, özel sektörde uygulanmakta olan iç kontrol, risk yönetimi ve iç denetim kavramları kamu sektörümüzde yerini almiştır.

\section{KURUMSAL RİSK YÖNETIMİ KAVRAMI}

İnsanlar, her çeşit durumda tanımlamak, değerlendirmek, idare ve kontrol edebilmek amaciyla risk yönetimini uygularlar. $\mathrm{Bu}$ durumlar, bir proje veya piyasa riski gibi dar tanımlı risk türlerinden, örgütün genelini ilgilendiren firsat ile tehditlere varıncaya kadar çok farklı konularda olabilir. Bir örgütün yönetişim süreçlerini geliştirme olanağı vermesi nedeniyle, kurumsal risk yönetimi (KRY) özellikle önem arz etmektedir. En çok benimsenen KRY tanımı, Treadway Komisyonu Sponsor Örgütler Komitesi (COSO) tarafından 2004 senesinde yayınlanan KRY Entegre Çerçevesi ile tanımlanmıştır. Ancak zamanla risk türleri, risklerin nedenleri, risklere karş11ık yapılacak uygulamalar değer üretebilen mekanizmalar olmaktan uzaklaştırmıştır. COSO, KRY Çerçevesini 6 Eylül 2017 tarihinde revize etmiştir. Güncellenen çerçevede KRY; “Organizasyonların değer yaratmada, korumada ve realize etmede, riskleri idare etme yönünde güvenecekleri, strateji belirleme ile yürütmeye entegresi sağlanan, kültür, olanak ile prosedürlerdir", şeklinde tanımlanmıştır (COSO, 2017:1). Oluşturulan yeni KRY çerçevesinde KRY'nin statik olmadığı, tüm seviyelerdeki yönetim ve risk süreçlerine uygulanabileceği belirtilmiştir. KRY'nin ana hedefi (Arslan, 2008:7);

\section{"risk yönetim süreciyle yönetim süreçlerini bütünleştirmek olumlu ya da olumsuz etki meydana getirebilecek ilerideki hadiseleri belirlemek, kurumların bu hadiselerden hangi seviyede etkileneceklerini gösteren unsurlarla yüzleşme düzeyini tespit edip idaresini sağlamak yönünde etkin stratejiler oluşturmaktır."}

KRY'nin arkasındaki dayanak, her örgütün paydaşlarına değer katmak için varoluşudur. Bütün örgütler belirsizliklerle karşılaşmaktadır. Bu durumda yönetimin yapması gereken, paydaş değerini artırmaya çalışırken, ne kadar bir belirsizliği karşılayabileceğine karar vermek olmalıdır.

Risklerin yönetilmesinden asıl sorumlu olan merci yönetim kuruludur. İç denetçilerin KRY'deki rolü ise, danışmanlık ve izleme faaliyetidir (IIA, 2009:6). Eğer bu konularda, iç denetim birimleri (IDB) bünyesinde gerekli bilgi birikimi ve deneyim yoksa dış kaynaklardan destek alınmalı, aksi takdirde danışmanlık ve izleme faaliyetlerinde bulunulmamalıdır. Mevcut uygulamalarda, yönetim kurulu, risklerin yönetilmesi ve yürütülmesini bir yönetim takımına devretmektedir. Bu faaliyetlerin koordinasyonunu yürüten, proje temelinde idare eden, ilgili profesyonellik gereksinimini sağlayan farklı bir bölüm de bulunabilir. Başarılı bir KRY uygulamasında örgüt genelindeki bütün çalışanların sorumluluğu vardır, fakat risk tanımlaması ile yönetilmesi rolleri yönetime aittir. İç denetim ve risk yönetimi birtakım özellikli yetenek, bilgi ile değerleri yönetim ve kurum çalışanları ile paylaşır. Proje yönetimi, çözümleyici ve kolaylaştırıcı yeteneklere sahiptir, uygun risk dengeleri oluşturmaya çalışır. Riskle ilgili yöneticiler örgüt yönetimine tabi çalışır, denetim komitesine bağımsız-tarafsız güvence sağlamak şeklinde rolleri bulunmamaktadır. 
Belirttiğimiz hususlar çerçevesinde KRY özetle, kurumların ne kadar risk üstlenmek istediklerini, risklerin nasıl oluştuğu ve stratejik tercihlerle azaltılması ile gelişmekte olan risklerin nasıl kurumları etkilediğiyle ilgilenmektedir (COSO, 2012:174). Kamu yönetimi açısından baktığımızda risk büyük öneme sahiptir. Eğer bir şey yönetiliyorsa bizatihi kendisi risk demektir, yani aslında yönetilen risktir. İnsan kaynakları ve bütçe risk taşır. Kamu kesiminde bütün risklerin faturasının kesildiği yer kamunun bizatihi kendisidir (Aktaş, 2015:103). KRY alanında kamuda farkındalığa sahip örgütler yönetişim konusunda iyi örnek uygulamaları vermektedir. KRY, örgütlerde karar alma süreçlerinin bir parçası haline getirilmediği takdirde anlamsız yeni iş yükü oluşturmaktan öteye geçememektedir (Uysal, 2018:43).

\section{RISKK ODAKLI İÇ DENETIM}

KRY anlayışı ile iç denetim de risk yönetimi esaslı denetime geçmiştir. Risk esaslı denetim yaklaşımında risklerin kabul edilebilir düzeye düşürülmesi temel vurgu iken, risk yönetimi esaslı denetim yaklaşımında ise kurumsal hedeflere ulaşmak için gerekli olan kilit risklerin optimize edilmesi önem kazanmaktadır (Kıral, 2014:327).

İç Denetçiler Enstitüsü tarafından iç denetim, kurumların risk yönetimi, kontrol ile yönetişim prosedürlerinin etkin olup olmadığını analiz etmek ile geliştirmek için sistemsel bakış açısı oluşturmak ve bu suretle kurumların hedeflerine varmasına yardım etmek şeklinde belirtilmiştir (IIA, 2019:1). Tanımdan görüldüğü üzere iç denetim faaliyetinin kapsamı, örgütlerin her düzeyde yönetim tarafindan tasarlanan ve yürütülen risk yönetimi, kontrol ile yönetişim prosedürleri ağının kâfi olup olmadığını tespit etmektir. İç denetim, etik ve değerleri kurum içinde desteklemeyi ve suistimal riskini yönetmeyi sağlayacak şekilde de çalışmalıdır.

İç denetimin risk yönetimine dair esas rolü, etkin bir risk yönetim sistemi yürütülüp yürütülmediği hususunda üst yönetime güvence vermektir. Katma değer yaratma yönü, kamu kesiminde uygulanan uygunluk denetimine KRY ile kontrol süreçlerini değerlendirmeyi ilave ederek denetimin yaklaşımını günümüz koşullarına uygunlaştırmadır. Etkili bir denetim yaklaşımı, iç kontrol sisteminin yeterli olup olmadığının değerlendirilmesinde geçmişte yapılmış işlemlerin üzerine durmaktan ziyade, kaynakların belirlenen hedefler doğrultusunda kullanılıp kullanılmadığı ve faaliyetlerden doğabilecek riskleri azaltmayı kapsamaktadır (Jiang vd., 2018:287).

Bu konuda araştırmalar da, önemli risklerin gerektiği gibi yönetilip yönetmediği ve KRY ile iç kontrol süreçlerinin etkin bir şekilde yürütülmesi konularında güvence vererek iç denetimin kurumlara değer kattı̆̆ 1 hususunda iç denetim unsurların hemfikir olduklarını belirtmektedir (IIA, 2009:4). Uluslarası iç denetim standardı 2010.C1 İç Denetim Yöneticisinden, risk yönetimini iyileştirme, değer katma ve örgütün faaliyetlerini iyileştirme üzerine danışmanlık taleplerini değerlendirmesini içermektedir. Danışmanlık talepleri kabul edilebilir veya reddedilir.

Örgütlerin Türk Ticaret Kanunun getirdiklerini göz önünde bulundurarak, insan kaynaklarını, teknolojilerini ve yetkinliklerini ivedilikle değerlendirmeleri, gereksinimleriyle alakalı doğru faaliyet ile çözüm paydaşlarını seçebilmeleri eğitim ve bilgi süreçlerini oluşturmaları lazımdır. Bu süreçte örgütlerin iç denetim faaliyetini mutlaka kullanmaları tavsiye edilmektedir. Uluslararası İç Denetim Standartları'na paralel bir şekilde, Kamu İç Denetim Standartları yayımlanmıştır. Zamanla iç denetim faaliyetlerinin tüm kamu kurumlarında yaygınlık kazandığı da görülmektedir.

\section{TEFTISS VE KAMU IÇ DENETIM SISTEMI}

Ülkemizde uygulanan hâli hazırdaki denetim sistemi teftiş ağırlıklıdır. Audit kavramıyla belirtilen denetim sistemine nazaran inspection kavramıyla açıklanabilecek teftiş sisteminin noksanlıkları bulunmaktadır. Günümüz teftiş kurullarının daha ziyade düzenlilik denetimine ağırlık vererek faaliyet denetimi yapmaları sebebiyle yolsuzluk doğuran sistemin giderilmesi hususunda gerekli desteği yapmamaktadırlar. Genel kabul gören denetim standartlarının olmamasından, gelişen denetim yaklaşımlarından faydalanmamalarından, denetim raporlarının kamuoyu ile paylaşılmamasından, denetleyen ile denetlenenler arasından güvensizlikten kaynaklanan eksiklikler gibi zayıf yönleri bulunmaktadır (Kaplan, 2007:20).

Kamu idarelerine birden fazla aynı görevi yapan denetim birimi olmamalıdır. Birçok kamu idaresinde önceden var olan teftiş kurulları görevlerine devam ederken benzer misyon yüklenmiş İDB'ler de kurulmuştur. Kamu idaresinde iç denetimden başka denetim birimlerinin bulunması hâlinde, denetim birimleri arasında uyumun 
sağlanabilmesi için, denetim birimlerinin görev alanları, işbirliği yapılabilecek konular ve benzeri hususlar yapılacak hukuki düzenlemelerle belirlenmelidir (Bilge ve Kirac1, 2011:164). Denetçiler, müfettişler ile düzenleyicilerin rolleri rolleri farklı olmakla birlikte birbirlerini tamamlayan süreçleri kapsamaktadır. Denetim ile düzenleme sistemleri değişkendir. Geleneksel denetim yaklaşımı olarak teftiş; "hizmetlerin ulusal ve bölgesel performans standartlarını, kanuni ve isssel gereksinimleri ile hizmetlerin kullanıcı gereksinimlerini giderilip giderilmediği hususunda bağımsız kontrol temin eden ve raporlama yapann dönemsel ve hedefli bir inceleme prosedürüdür" (Public Audit Forum, 2002:18).

Teftiş ile iç denetim arasındaki bir diğer fark ise, teftişin belirsiz zamanlarda ve arzu edildiğinde yapılan, iç denetimin ise idarenin birimlerine periyodik olarak yaptırdığı faaliyet oluşudur (Okur, 2010:575). Teftiş ve iç denetim sistemlerinin karşılaştırılması Tablo 1'deki gibi belirtilebilir.

Tablo 1. İç Denetim İle Teftiş Farkı

\begin{tabular}{|c|c|}
\hline İç Denetim & Teftiş \\
\hline İnsan odaklıdır. Güven esaslıdır. & Devlet-Bürokrasi merkezlidir. \\
\hline Risk esaslı denetim yöntemi bulunmaktadır. & Risk değerlendirmesi tecrübeler yoluyla belirlenir. \\
\hline Denetim maliyetleri dikkate alınmaktadır. & Denetim maliyetleri sorgulanmamaktadır. \\
\hline Denetçinin performansı daima ölçülür. & $\begin{array}{l}\text { Denetçi performans değerlendirme kıstasları kısıtlıdır ve teamüllere } \\
\text { göredir. }\end{array}$ \\
\hline $\begin{array}{l}\text { Uluslararası denetim standartları ile belirlenen denetim teknikleri } \\
\text { kullanılmaktadır. Risk odaklı, sistematik prosedür denetimi yapar. } \\
\text { Proaktiftir. }\end{array}$ & $\begin{array}{l}\text { Uygunluk denetimi ile yolsuzluk mücadelesini ölçmektedir. Mevzuat } \\
\text { uygunluğunu baz alır. Kişi, hadise ve işlem bazlı denetim yapmaktadır. } \\
\text { Reaktiftir. }\end{array}$ \\
\hline $\begin{array}{l}\begin{array}{l}\text { Mesleki yeterlilik doğrultusunda daimi ve sistemsel eğitim } \\
\text { bulunmaktadır. }\end{array} \\
\end{array}$ & Düzensiz, kesintili hizmet içi eğitim bulunmaktadır. \\
\hline İdareye makul güvence verir. & $\begin{array}{l}\text { İdare uygulamalarındaki hataları belirlemek yoluyla idareye güvence } \\
\text { verir. }\end{array}$ \\
\hline İdareye daimi danışmanlık sağlar. & İdareye denetim öncesinde ve sonrasında her vakit tavsiye verir. \\
\hline Sistem ile prosedür bazlı denetim yapmaktadır. & Örnekleme suretiyle denetim yapmaktadır. \\
\hline Tepe yöneticiye bağlıdır. & Çeşitli otoritelere bağlıdır. \\
\hline Bütün denetim çeşitlerini içerir. & İdaresel iş ile işlemlerin tamamına odaklıdır. \\
\hline Riskleri tespit etmek ile öneriler geliştirmek asıl görevidir. & Yolsuzlukları belirlemek asıl görevlerinden birisi. \\
\hline Gelecek odaklıdır. & Geçmişe bakar. \\
\hline Yazılı kuralları bulunur. & Yazı kurallarından çok teamüllere bağlıdır. \\
\hline Çalışma ve raporlama anlayışı standarttır. & $\begin{array}{l}\begin{array}{l}\text { Çalışma ve raporlama } \\
\text { gösterebilir. }\end{array} \\
\text { anlayışı kurumdan kuruma değişiklik }\end{array}$ \\
\hline
\end{tabular}

Kaynak: Gürkan, 2009:129.

\section{TÜRKIYE TARIM KREDİ KOOPERATIFLERİ İÇIN BIR MODEL ÖNERISII}

Tarım Kredi Kooperatiflerinin kurulması Mithat Paşa'nın 1863 senesinde “Memleket Sandıkları"nı kurmasına dayanmaktadır. T.C. Ziraat Bankası bünyesinde faaliyetlerini devam ettirmekte iken 1972 senesinde 1581 numaralı "Tarım Kredi Kooperatifleri ile Birlikleri Yasası" sayesinde Bölge Birlikleri ile Merkez Birliğine kuruluş imkânı tanınmış ve 1977 senesinde Merkez Birliğinin kurulması ile birlikte bağımsız bir yapıya kavuşarak dikey teşkilatlanmasını tamamlamıştır. Tarım Kredi Kooperatiflerinin denetimi 1985 senesinde Gıda, Tarım ve Hayvancılık Bakanlığı'na verilerek bakanlığın ilgili kurumu şekline gelmiştir. Günümüzde Tarım Kredi Kooperatifleri, 1611 Kooperatif ile bunların bağlı olduğu 17 Bölge Birliği ile Bölge Birliklerinin çatısını oluşturan Merkez Birliği aracılığıyla ortakları ile çiftçilerin her çeşit ihtiyacını gidermeye yönelik mal ile hizmeti sağlayan, ürünlerini pazarlayan ülkemizin en geniş çiftçi ailesidir. Tarım Kredi Kooperatifleri faaliyetlerine 4500'ün üzerine personeli ile birlikte Türkiye Tarım Kredi Kooperatiflerine bağlı 11 iştirak ve bir milyonun üzerine çiftçi ortağı ile devam ettirmektedir (Aydın ve Atılgan Yaşa, 2019:359).

Birçok kamu kurumunda olduğu gibi Türkiye Tarım Kredi Kooperatiflerinde de risk yönetimi ve iç denetim uygulamaları doğrultusunda girişimler yapılmaya çalışılmaktadır. Çiftçiye en fazla destek veren kuruluş olmasından dolayı ülkemizin elzem kuruluşlarından biri olma vasfı taşımaktadır. $\mathrm{Bu}$ şekilde elzem bir kuruluşun, iç denetimi etkin olarak gerçekleştirmesi gerekmektedir (Kara, 2011:112). 
Türkiye Tarım Kredi Kooperatiflerinde KRY ve iç denetim konularında çeşitli çalışmalar başlamış bulunmakla birlikte, bunlar başlangıç seviyesinde kalmıştır. Bu konularda gerekli kurum kültürü yerleşmemiş ve KRY çerçevesinde geleceğe yönelik risklerin önlenmesinden ziyade, geçmişe yönelik hata ve suistimallerin incelendiği uygunluk denetimleri yapılmaktadır. Belirtilen hususlar doğrultusunda bu çalışmada Türkiye Tarım Kredi Kooperatifleri için risk odaklı bir iç denetim ve KRY süreci hakkında model önerisinde bulunulacaktır.

\subsection{Türkiye Tarım Kredi Kooperatiflerinin Teşkilat Yapısı ve Mevcut Denetim Süreci}

Türkiye Tarım Kredi Kooperatiflerinde denetim müessesesi, genel müdür adına denetim, inceleme ve soruşturma yapan Rehberlik ve Teftiş Kurulu Başkanlığı bünyesindeki müfettişler ile bağlı bölge birliklerinde bölge müdürü adına denetim yapan kontrolörler marifetiyle yürütülmektedir. Denetimlerde bağımsızlık düzeyinin artması durumunda, risk odaklı denetimin etkinliği de artacaktır. Denetim faaliyetlerinin bağımsızlık prensibi doğrultusunda yapılması hâlinde, işlemler usulüne uygun gerçekleşecektir (IIA, 2019:47).

Türkiye Tarım Kredi Kooperatiflerinde risk yönetimi konusunda yapılan çalışmalara aşağıdaki gibi özetlenebilir:

- Ortak çiftçilerin kredi ve borçlanma işlemleri yapılırken diğer banka ve finans kuruluşların risk merkezi kayıtları dikkate alınarak hareket edilmesi amacıyla Türkiye Bankalar Birliği Risk Merkezi ile anlaşma yapılmıştır.

- Ortakların yükümlü oldukları borçların kredi limitlerine göre oldukça yüksek olması nedeniyle ve kooperatif alacaklarının tahsil edilebilirlik kabiliyetini artırmak üzere, kefaletle kredi kullanan ortaklara verilebilecek kefalet tutarı kefalet verene ait en son geçerli sözleşme limitinin 10 katına karşılık gelen tutarı ve her hâlükârda ise 15 ortağ 1 geçemeyecek şekilde müşterek ve müteselsil kefillik sistemi getirilmiştir. Böylece kredilerin geri dönüş riski, minimize edilmeye çalışılmıştır.

- İç kontrolün etkin olup olmadığını gözetmek amacıyla 2016 senesinde İştirakler Daire Başkanlığına bağlı olarak İştirakler Kontrol Müdürlügüü kurulmuştur. Müdürlügü̈n kurulmasıyla birlikte iştiraklerden Tarım Kredi Yem AŞ’ye SMMM ve bağımsız denetçilik sertifikalarına sahip iki emekli müfettiş iç denetçi olarak atanmış olup bölge birliklerine bağlı iki kontrolör de iç denetim faaliyetlerine destek amacıyla görevlendirilmiştir. Atanan iç denetçiler her ne kadar Tarım Kredi Yem A.Ş. kadrosunda olsalar da diğer iştiraklerinde iç denetim faaliyetlerini yürütmektedir. Merkez Birliği, Bölge Birlikleri ve kooperatiflerde iç denetim faaliyeti bulunmamaktadır. İştirakler Kontrol Müdürlüğünce, İştirakler İç Denetim Yönetmeliği hazırlanmaktadır. İç denetim faaliyetlerine bakıldığında, iç denetçilerin klasik teftiş anlayışıyla denetim yaptığı, iç denetim konusunda uzman olmayan kişilerin görevlendirildiği ve yapılan denetimlerin iç denetim standartları çerçevesinde yürütülmediği görülmektedir.

- Türkiye Tarım Kredi Kooperatiflerinde risk yönetimi kapsamında Sigorta Müdürlügü̈, Sigorta ve Risk Yönetim Müdürlüğü şeklinde değiştirilmiş ve Krediler ve Mali İşler Daire Başkanlığı bünyesinde konumlanmıştır. Her sürecin risk analizlerinin yapılarak süreçlerin yönetilmesi gerekirken Türkiye Tarım Kredi Kooperatiflerinde risk yönetimi verilen kredilerin geri dönüşümünde karşılaşabilecek risklere karş1 önlem almakla sınırlı kalmıştır. Sigorta ve Risk Yönetimi Müdürlügü incelendiği zaman risk yönetimi konusunda hiçbir faaliyette bulunmadığı ve belirtilen amacının gerçekleştirilmesi konusunda da girişimlerde bulunulmadığ 1 gözlenmektedir.

- Türkiye Tarım Kredi Kooperatifleri 2011-2023 strateji belgesi ve eylem planına bakıldığında, denetim konusunda dördüncü hedef risk denetimi ağırlıklı faaliyet gösterilmesidir. Bu hedefin 2013 senesine kadar hayata geçirilmesi planlanmıştır (Türkiye Tarım Kredi Kooperatifleri, 2011, s. 152). Ama mevcut denetim usullerine bakıldığımızda, bu hedefin hayata geçirilememiş olduğu görülmektedir ve yapılan denetimler uygunluk denetiminin ötesine geçememiştir.

- İç denetim danışmanlık faaliyetlerinde olduğu gibi Teftiş Kurulu Başkanlığı'nın adı 2012 senesinde Rehberlik ve Teftiş Kurulu Başkanlığı şeklinde değiştirilmesine rağmen müfettişleri iş yoğunluğu sebebiyle denetimlerinde rehberlik faaliyetlerinde bulunamamaktadır.

Yukarıda görüldügü üzere Türkiye Tarım Kredi Kooperatiflerinde KRY ve bunun paralelinde risk odaklı iç denetim uygulamasına tam anlamıyla geçilmediği görülmektedir. Çalışmanın bundan sonraki bölümünde Türkiye Tarım Kredi Kooperatiflerinde risk esaslı iç denetim uygulanması için bir model önerisi sunulmaktadır. 


\section{2. İç Denetim Birimi ve Risk Yönetimi Model Önerisi}

Türkiye'de İDB'lerin yapılanmasına baktığımız zaman özel sektörde Yönetim Kurulu/İcra Komitelerine bağlı iç denetim ve risk yönetim unsurlarından oluşan denetim komiteleri görülürken kamuda Rektör, Bakan/Bakan Yardımcısı ve Belediye Başkanlarına bağlı olup Teftiş Kurulları ile birlikte çift başlı denetim yapısı bulunmaktadir.

Yasayla kurulan ve bakanlığın ilgili kuruluşu gibi görev yapan bir kooperatif kurumu olan Tarım Kredi Kooperatiflerinin çalışma şekline baktığımız zaman özerk bir kurum şeklinde faaliyet gösterdiği görülmektedir. Tarım Kredi Kooperatifleri Merkez Birliğinde üst yönetici olarak Yönetim Kurulu tarafından atanan Genel Müdür görev yapmaktadır. Genel Müdür genel kurula katılma hakkına haiz en az ilkokul mezunu ortak çiftçilerden oluşan temsilciler arasından dört yıllığına seçilen 9 üyeli Yönetim Kuruluna bağlıdır (Türkiye Tarım Kredi Kooperatifleri, 2008:149). Tarım Kredi Kooperatiflerinde yönetim kurulu üyelerinin belirtilen vasıflarından dolayı İDB'nin Genel Müdüre bağlı olarak çalışması yerinde olacaktır.

İDB'nin kurulmasıyla birlikte Tarım Kredi Yem A.Ş. bünyesinden iç denetçiler alınarak İDB bünyesine dâhil edilmesi, başta müfettişler olmak üzere kontrolörlerin eğitim programlarına alınarak İDB kadrosu tamamlanabilir. Ayrıca bu iç denetçilerin profesyonel sertifika almaları teşvik edilebilir. Bilişim Teknolojileri konusunda denetim yapmaları da sağlanabilir. Bu şekilde Türkiye Tarım Kredi Kooperatiflerince ihtiyaç duyulan danışmanlık hizmetleri iç denetçiler aracılığıyla da gerçekleştirilebilir.

Model önerimiz doğrultusuna KRY faaliyetleri çerçevesinde etkin bir işleyişin kazandırılması için Teşkilatlandırma ve Halka İlişkiler Daire başkanlığına bağlı olan Strateji Geliştirme ve Koordinasyon Müdürlüğünün Strateji Geliştirme Başkanlığı (SGB) olarak yeniden yapılandırılmalıdır. Krediler ve Mali İşler Daire Başkanlığına bağlı Sigorta ve Risk Yönetimi Müdürlüğü’nün iki ayrı birime ayrılmalıdır. Bu şekilde Risk Yönetimi Birimi kurulacak SGB altında yapılandırılması ve Risk Yönetimi Biriminin Sigorta Yönetimi Daire Başkanlığı şeklinde yapılandırılması sağlanabilir. Ayrıca kurulacak SGB'ye bağlı İç Kontrol ve Uyum Müdürlüğü oluşturulabilir. Bu müdürlükte uzman kadrosu adı altında gerekli eğitimler verilmesi yoluyla iç kontrol uyum görevlileri ihdas edilebilir.

Tarım Kredi Kooperatiflerine bağlı iştiraklere baktığımız zaman bunların yem, ilaç, gübre, ilaç, plastik, sigorta ile emeklilik, gıda, bilişim ve hayvancılık alanlarında faaliyet gösteren Türkiye'nin önde şirketleri olduğu görülmektedir. Bu iştirakler, Tarım Kredi Kooperatifleri Merkez Birliği İştirakler Daire Başkanlığına bağlıdır. Merkez Birliği bünyesinde oluşturulacak bir İDB vasıtasıyla bunların denetimleri gerçekleştirilebilir.

Mevzuat çalışmaları kapsamında İştirakler İç Denetim Yönetmeliğinin yanında Merkez Birliği müdürlüklerini, Bölge Birlikleri ile Kooperatifleri de kapsayacak iç denetim yönetmelikleri, risk yönetimi ile iç kontrol yönetmeliklerinin de oluşturulması sağlanmalıdır.

Türkiye Tarım Kredi Kooperatiflerinde tüm kurum faaliyetleri "e-koop” adı verilen internet tabanlı otomasyon sistemi aracılığıyla yapılmaktadır. Müfettiş ile kontrolörler teftiş modülü sayesinde denetimlerini yürütmektedir. Otomasyon sistemine bir risk yönetim modülü eklenmelidir. Böylece her birim, süreç ve faaliyet ile ilgili riskler tespit edilip bunların yönetilmesi sağlanabilir. Modül yönetimi birim yöneticileri ve SGB tarafından gerçekleştirilebilir. Kurulacak olan IDB kendi tespit ettiği riskli alanları ile birlikte denetim plan ve programına risk yönetimi modülünden gelecek verileri de göz önüne alabilir. Ayrıca müfettiş ve kontrolörler denetimlerini otomasyon teftiş modülü üzerinden gerçekleştirmektedir. İDB içinde otomasyon sistemine İç-Den programının benzeri bir modül kurulması sayesinde iç denetim faaliyetlerinin yürütülmesi sağlanabilir.

İç ve dış denetimlerin etkinlik, katma değer, muhasebe, finansal raporlama, kontrollerin işleyişiyle yeterlilikleri bakımından yönetim kurulu adına gözeten "denetim komiteleri” oluşturulması gerekmektedir. Yönetim Kurulu üyelerinden denetim komitesi oluşturma imkânı bulunmuyorsa yönetim kurulu üyelerince seçilecek kişilerden oluşturulabilir. Denetim komitesi, denetim kurulundan farklı bir yapıdır. Dünya uygulamalarında denetim komitesi üyelerinin seçiminde şirket genel müdürünün her ne kadar sınırlı katılımı tavsiye edilse de komite üye adayları ile komiteye takviye ihtiyaç duyulması hâllerinde şirket genel müdürüne danışılması gerekmektedir. Denetim Komitesi üyeleri hukuk işleri, iç ve diş denetim, finans ve muhasebe, risk yönetimi, bilgi teknolojileri ve bilgi güvenliği, düzenlemelere uyum, sektör ve gelen işletme bilgisi konularında hâkim kişiler arasından seçilmelidir (TÜSİAD, 2012:13). Bu hususlar çerçevesinde ve Tarım Kredi Kooperatiflerinin Yönetim Kurulunun yapısı da dikkate alınarak Denetim Komitesinin genel müdür tarafından seçilecek ilgili kişilerden oluşturulması gerekmektedir. Dolayısıyla çeşitli uygulama örneklerinden hareketle İDB Başkanı, İç Kontrol ve Uyum Müdürü, Risk Yönetimi Müdürü, Rehberlik ve Teftiş Kurulu Başkanından meydana gelen bir Denetim 
Komitesi oluşturulabilir. Bu komiteye SGB Başkanı da dâhil edilebilir. Tarım Kredi Kooperatifleri 5018 numaralı Yasa dâhilinde olmadığı için kurulacak iç denetim İç Denetim Koordinasyon Kurulu izlemesine tabi olmayacaktır. Dolayısıyla bunun yerine özel sektörde olduğu gibi Denetim Komitesi uygulamasının hayata geçirilmesi yerinde olacaktır.

Türkiye Tarım Kredi Kooperatifleri Merkez Birliği teşkilat yapısında ilgili birimler Şekil 1'deki gibi yeniden yapılandırılabilir. Bu birimlerin birbiriyle koordineli şekilde Şekil 2'de belirtildiği gibi faaliyetlerini yürütmesi sağlanabilir. Hem IDB hem de Teftiş Kurulundan oluşan kamu kurum içi denetim mekanizması, şekillerden de görüldüğü üzere model önerimizde, özel sektör denetim komitesi ile birleştirilmiştir.

Şekil 1. Türkiye Tarım Kredi Kooperatifleri Teşkilat Model Önerisi

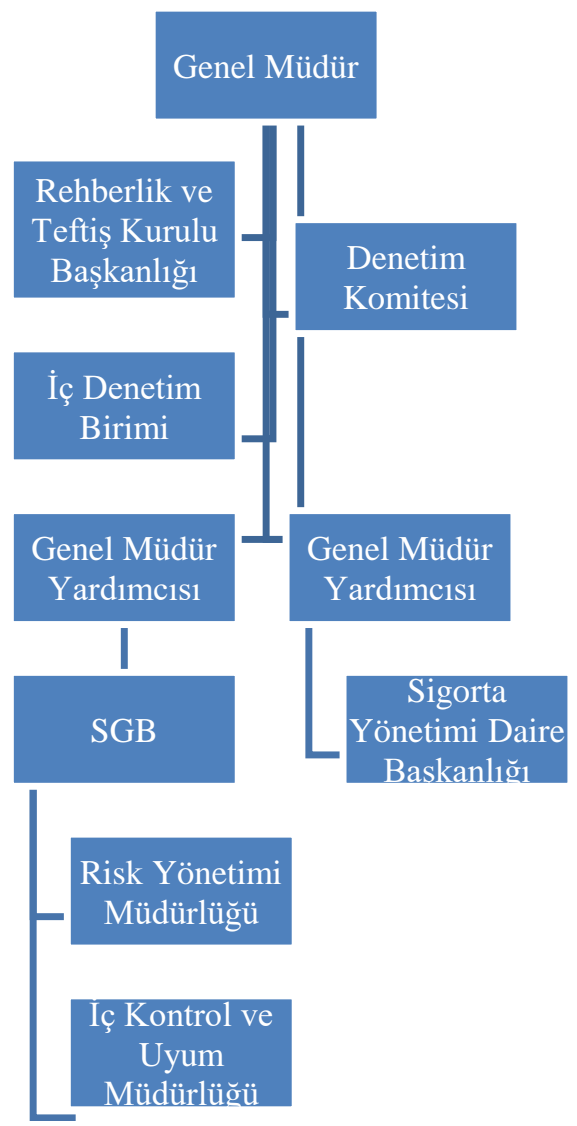

Kaynak: Şekil bu çalışma için yazar tarafindan oluşturulmuştur.

Şekil 2. Türkiye Tarım Kredi Kooperatifleri Denetim Komitesi Model Önerisi

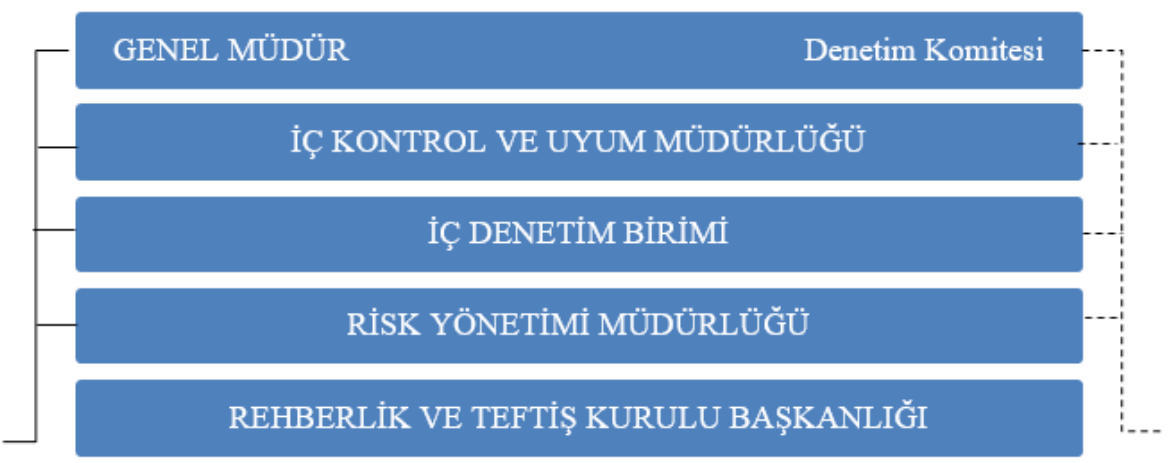

Kaynak: Şekil bu çalı̧̧ma için oluşturulmuştur.

Bu doğrultuda kurulacak olan IDB ile iştiraklerde Rehberlik ve Teftiş Kurulu Başkanlığınca teftiş yaklaşımıyla yapılan denetimler İDB'ye devredilebilir. İnceleme soruşturma faaliyetleri iç denetimin görev kapsamında olmadığı ve bağlı kooperatif sayısının oldukça yüksek olması nedeniyle kooperatiflerde yürütülen teftiş 
çalışmalarının Rehberlik ve Teftiş Kurulu Başkanlığınca yapılmasına devam edilebilir. Bölge Birlikleri ve Merkez Birliği birimlerinin denetimlerinin İDB'ye devrolunması sağlanabilir.

\subsection{1. İç Denetim Güvence/Denetim Faaliyeti Model Önerisi}

Türkiye Tarım Kredi Kooperatiflerinde hiç uygulanmayan risk odaklı İç denetim uygulaması için iç denetim metodolojisi çerçevesinde faaliyetlerini gerçekleştirecek IDB model önerisi Şekil 3'de gösterildiği gibidir. Bu doğrultuda denetim evreninin belirlenmesi, denetim paketinin belirlenmesi ve önceliklendirilmesi, iç denetim planının ve programının hazırlanması, görevlendirme, denetlenen birime bildirim, açılış toplantısı, risklerin belirlenmesi ve değerlendirilmesi, çalışma planının hazırlanması ve onaylanması, test kâğıtlarının kaydı, bilgilerin paylaşılması, kapanış toplantısı ve raporlama aşamaları yürütülebilir.

Şekil 3. Türkiye Tarım Kredi Kooperatifleri İç Denetim Süreci Model Önerisi

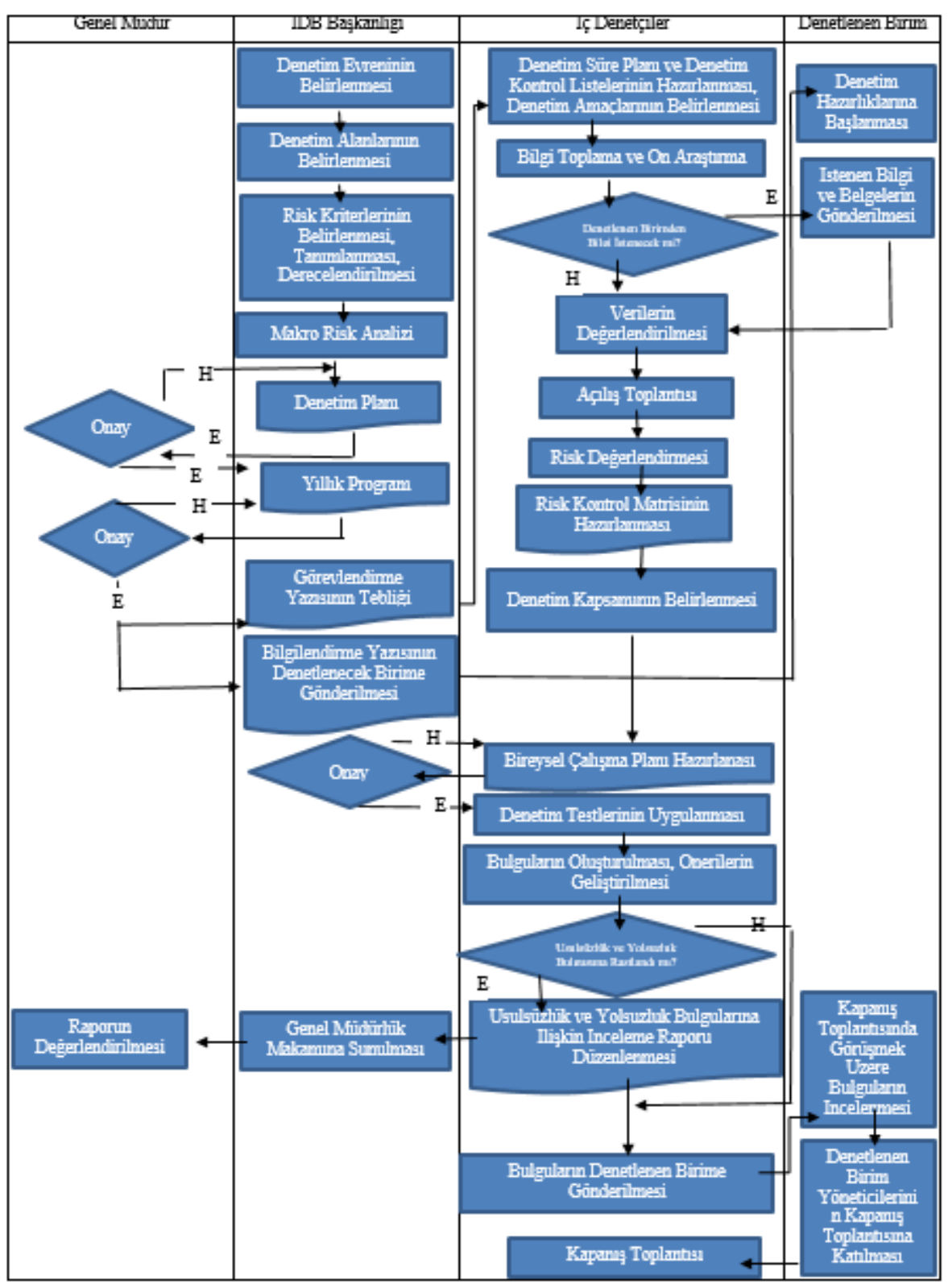

Kaynak: F. Ü. İç Denetim Birimi, 2013a)'den esinlenerek bu çalışma için oluşturulmuştur.

\subsection{2. İzleme}

Kamu İç Denetim Standartları uyarınca iç denetim, denetim ve danışmanlık faaliyetleriyle kurumlara katma değer sağlayabilmesi için, raporlarda yer alan önerilerin birimlerin belirttiği eylem planları doğrultusunda, 
gerçekleştirilip gerçekleştirilmediğinin izlenmesi gerekmektedir. İDB Başkanı, denetim kaynağını göz önüne alarak, izleme faaliyetleri için de iç denetçi görevlendirebilir. Raporlarda belirtilen önerilerin gerçekleştirildiğine kanaat edinilmişse "Tamamlanmıştır" olarak bulgu kapatılırken, eksikliklerin tespit edilmesi hâlinde eylemin karmaşıklığına göre 24 aya kadar ek süre verilmektedir. İlerleme kaydedilmeyen öneriler "Risk Üstlenildi” şeklinde kapatılarak üst yöneticiye bildirilmektedir. Bulguların kapatılmasının ardından ilgili denetim alanının risk seviyesi, IDB Başkanı tarafından denetim güncellemektedir. Bu doğrultuda, Türkiye Tarım Kredi Kooperatifleri için izleme süreci Şekil 4'deki gibi oluşturulabilir.

Şekil 4. Türkiye Tarım Kredi Kooperatifleri IDB İzleme Süreci Model Önerisi

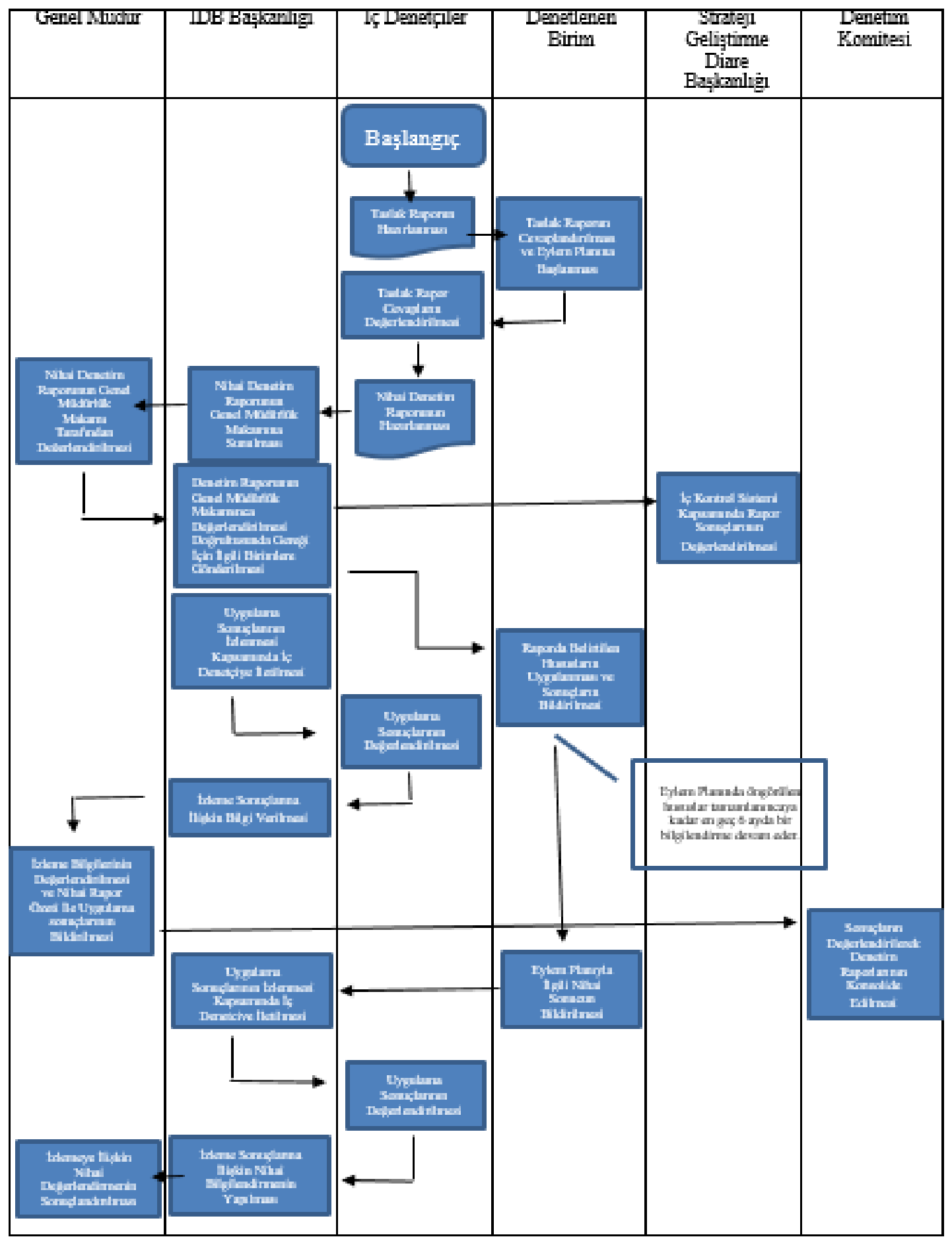

Kaynak: F. Ü. İç Denetim Birimi, 2013b’den yararlanılarak hazırlanmıştır. 
Kamu yönetimi alanında meydana gelen gelişmeler doğrultusunda, iç denetime gösterilen önem yükselmiştir. KRY çerçevesi, güven teminatı bakımından iç denetim faaliyetini göstermektedir. Fakat risk denildiğinde, kamudaki birtakım üst yöneticiler iç denetimi sigorta faaliyeti şeklinde algılamaktadır. İç denetim, bu konularda yönetimde farkındaklık oluşturur, tecrübe ile bilgileriyle danışmanlık faaliyeti gerçekleştirir. Ülkemizde kamu sektörüne risk terimini gündeme taşıan İDB'lerdir, fakat risk yönetim sürecinde iç denetim konumları gereğince aktif görev alamamaktadırlar. İç denetçiler, yaptıkları denetim ile danışmanlıklar doğrultusunda, yönetici ile çalışanların risk idare süreçlerinde aktif görev yürütmeleri hususunda raporlama yapmaktadır, fakat farkındalık yeterli seviyede bulunmaması sebebiyle netice arzu edilen düzeyde gerçekleşememektedir.

Kurumsal bir yönetiminin oluşabilmesi için, olay eksenli çalışmanın terk edilip, risk esaslı çalışmaya geçilmesi, bir gereklilik olarak kendini göstermektedir. Kamu faaliyetlerinin, KRY esaslarına göre yürütülmesi durumunda, günümüzde yaşanan olayların birçoğunun vuku bulmayacağını söyleyebiliriz.

Ülkemizde 5018 numaralı Yasa ile kamu yönetiminde önemli bir değişim yaşanmış ve bu yeni yönetim anlayış1 ile uluslararası genel kabul görmüş bazı kontrol yaklaşımları yönetim sistemimizde uygulanmaya başlamıştır. Ancak gelişimeler ile birlikte birtakım dirençlerin görülmesi de olağandır. Kamu sektöründe de bu konularda birtakım dirençlerin bulunduğu anlaşılmaktadır. Kamu sektöründe, özellikle köklü ve büyük teşkilat yapısı bulunan, bu sebeple de muhafazakâr görüşlerin yer edindiği kurumlarda, bu değişim daha zor olacağ 1 anlaşılmaktadır. Çünkü örgütsel gelişim ile dönüşüm, mevzuatsal düzenlemelerin yanında, personelin görüş ve yeteneklerini de değiştirmesiyle mümkün olabilmektedir.

Öte taraftan araştırmamıza göre, Türkiye Tarım Kredi Kooperatiflerinde üst yönetimde tam anlamda KRY ve iç denetim faaliyetlerini destekleyen farkındalık bulunmadığı, ayrıca personelin konular hakkında yeterli eğitimlerinin bulunmadığ görülmektedir.

Bu çalışma kapsamında, Türkiye Tarım Kredi Kooperatiflerinde risk odaklı bir sistemin kurulması konusunda, aşağıda belirtilen öneriler geliştirilmiştir;

- Böyle önemli bir kurumun, KRY ve iç denetim uygulamalarını öncelikleri arasına alması yerinde olacaktır. Risk odaklı iç denetim sistemi kurularak kurum faaliyetlerine katkı sağlanması ve iç denetimin risk yönetimine de artı değer sağlaması faydalı olacaktır.

- İDB'nin kurum bünyesindeki işlevleri ve oluşturacağı katma değerler hususunda üst yöneticiler ile denetlenen birimler nazarında, farkındalık oluşturmaya yönelik eğitim çalışmaları yapılmalıdır.

- İç denetim kaynağı, ilk yıllarda özellikle danışmanlık faaliyetlerine tahsis edilmeli, iç denetçilerin KRY ve ilgi alanlarına giren her konuda daha fazla danışmanlık hizmeti yürütmeleri sağlanmalıdır.

- IDB başkanının görevleri ile kadro durumu hukuki olarak açık ve net bir şekilde belirlenmelidir.

- Yeterince iç denetçi istihdam edilmeli ve iç denetçilerin uluslararası sertifikaları almaları teşvik edilmelidir.

- Risk yönetimi sisteminin işletilmesine yönelik altyapılar tamamlanmalıdır: KRY sisteminde sorumluluk ile rollerlar, görevler, risk değerlendirmesi, sistemsel risk iştah ile toleransı, risklerin idaresiyle iç denetim bağı, risk raporlaması ile eylem planının izlenmesi için örgüt içi esas ve usuller belirlenmelidir. Ayrıca risk yönetiminin iyi bir KRY yazılımı ile desteklenmesi, uygulamaya pratiklik kazandıracaktır.

- Risk yönetiminde koordinasyon sağlayacak uzmanlar görevlendirilmeli ve bu uzmanların özellikle risklerin idaresi, KRY modelleri, proje yönetimi, risklerin raporlanmasıyla iletişim alanlarında bilgili olması, bu konularda uygulamalı eğitim ile danışmanlık alınması sağlanmalıdır.

Genel olarak denetim sisteminin mevzuat uygunluk denetimi şeklinde faaliyet gösterdiği göz önüne alındığ 1 takdirde, hâlihazırdaki sistemin yeniden değerlendirilmesi gerektiği belirtilebilir. Çünkü uygunluk denetimi yalnız başına iç denetim faaliyetinin başarı göstermesinde yetersiz kalacağı kabul edilmektedir. 


\section{KAYNAKÇA}

AKTAŞ, Burhanettin (2015), "Konferans Konuşması", Kamu İdarelerinde Daha Etkili Bir Yönetim İçin Nasıl Bir İç Denetim? Konferansı Kitabı (Ed. Ramazan DOĞANAY ve Mehmet Ali MEYDANLI), TBMM Basimevi, Ankara, ss.103-108.

ARSLAN, Işılda (2008), "Kurumsal Risk Yönetimi", Uzmanlık Tezi, Maliye Bakanlığı Strateji Geliştirme Başkanlığı Yayını, Ankara.

AYDIN, Ramazan ve ATILGAN YAŞA, Ayşe (2019), "Türkiye Tarım Kredi Kooperatiflerinin Mali Yapısı Üzerine Bir Değerlendirme", Sosyal Bilimler Enstitüsü Dergisi, S.(14), ss.352-368.

BİLGE, Semih ve KİRACI, Murat (2011), "Kamuda İ̧ Denetime Geçiş Sürecinde Iç Denetimin Başarlyla Uygulanmasında Rol Oynayan Faktörler: Kamu İç Denetçileri Üzerine Bir Araştırma”, Kamu Mali Yönetimi ve Denetimi Sempozyumu Bildiriler Kitabı, Ege Üniversitesi Yayını, İzmir.

COSO (2012), Internal Control-Integrated Framework: Framework and Appendices, PwC Publisher, Durham.

COSO (2017), Enterprise Risk Management - Integrateing with Strategy and Performance Executive Summary, COSO Publisher, Durham.

FIRAT ÜNIVERSITESİ İÇ DENETIM BİRIMI (2013a), "Denetim Süreci", İş Akış Şeması, Fırat Üniversitesi Yayın1, Elazı ğ, http://web.firat.edu.tr/icdenetim/img/denetim_sureci_1.jpg (Erişim Tarihi: 11.05.2020).

FIRAT ÜNIVERSITESI İÇ DENETIM BİRIMI (2013b), "Danışmanlık Süreci", İş Akış Şeması, Fırat Üniversitesi Yayını, Elazığg, http://web.firat.edu.tr/icdenetim/img/denetim_sureci_danismanlik.jpg (Erişim Tarihi: 11.05.2020).

GÜRKAN, Nazmi Arif (2009), "Türk Kamu Mali Yönetiminde İ̧̧ Denetim ve İ̧ Denetim Algısı", Yayımlanmamış Yüksek Lisans Tezi, Süleyman Demirel Üniversitesi Sosyal Bilimler Enstitüsü, Isparta.

IIA (2009), Pozisyon Raporu: İç Denetimin Kurumsal Risk Yönetiminde Oynadığı Rol, IIA Publisher, Lake Marry.

IIA (2019), Uluslararası İç Denetim Standartları - Uluslararası Mesleki Uygulama Çerçevesi-, TiDE Yayınları, İstanbul.

JIANG, Like, ANDRE, Paul E. Ve RICHARD, Chrystelle (2018), "An International Study of Internal Audit Function Quality", Accounting and Business Research, S.48(3), ss.264-298.

KAPLAN, Ahmet (2007), İngiltere'deki Kamu Denetim Sisteminin Genel Olarak Yapısı, İşleyişi ve Özel Olarak da Kültür Faaliyetlerine İlişkin Denetim Sisteminin Araştırılarak Türkiye'deki Denetim Sistemiyle Karşılaştırılması, (Yazarın Kendi Yayını), Ankara.

KARA, Mümine (2011), "Iç̧ Denetimde Risk Odaklı Yaklaşımın Başarısını Etkileyen Faktörlerin İncelenmesine Yönelik Bir Model: Türkiye Tarım Kredi Kooperatifleri Örneği", Yayımlanmamış Yüksek Lisans Tezi, Karadeniz Teknik Üniversitesi Sosyal Bilimler Enstitüsü, Trabzon.

KIRAL, Halis (2014), İç Denetim "Yönetime Değer Katmak", IDKK Yayınları, Ankara.

OKUR, Yaşar (2010), "Türkiye'de Teftiş ve İç Denetim: Kavramlar, Beklentiler ve Hayatla Yüzleşme", Maliye Derigisi, S.(158), ss.570-582.

PUBLIC AUDIT FORUM (2002), The Different Roles of External Audit, Inspection and Regulation: A Guide for Public Service Managers: Consultation Paper, National Audit Office Press, Londra.

TÜRKIYE TARIM KREDİ KOOPERATIFLERİ (2008), Tarım Kredi Kooperatifleri ve Birlikleri Temel Kanun - Mevzuatlar, TTKK Eğitim Müdürlüğü Yayını, Ankara.

TÜRKIYE TARIM KREDİ KOOPERATİFLERİ (2011), 2011-2023 Strateji Belgesi ve Eylem Planı, Türkiye Tarım Kredi Kooperatifleri Merkez Birliği Genel Müdürlüğü Yayını, Ankara.

TÜSİAD (2012), Uygulama Örnekleri İle Birlikte A'dan Z'ye Denetim Komiteleri, TÜSİAD Yayınları, İstanbul.

UYSAL, Maşuk Cahit (2018), “Kamu Kurumlarında Kurumsal Risk Yönetimi ve Risk Odaklı İç Denetim: $\dot{I}_{c ̧}$ Denetçiler Üzerine Bir Araştırma-II”, Denetişim, S.18, ss.35-44. 